\title{
The Alien Tort Statute of 1789 and International Human Rights Violations: Kiobel v. Royal Dutch Petroleum Co.
}

K iobel v. Royal Dutch Petroleum Co. involves an action under the Alien Tort Statute (ATS). The case was brought in the United States, Southern District of New York, by the widow of Dr. Barinem Kiobel, a Nigerian activist and member of the Ogoni tribe, and others for human rights violations committed in the Niger River Delta. Defendants include Royal Dutch Petroleum, Shell Transport and Trading Co., and Shell Petroleum Development Company of Nigeria. Although the buman rights violations including murder and torture were allegedly committed by the Nigerian military government, it is claimed that the Royal Dutch Petroleum defendants aided and abetted the Nigerian military in the buman rights violations. The plaintiffs had engaged in protests about the environmental damage caused by the Royal Dutch Petroleum defendants in the area of the Niger Delta and the plight of the Ogoni people in Ogoniland. At the trial level, the court decided that certain claims involving violations of the Law of Nations could be heard by the court. However, the case was appealed to the U.S. Supreme Court, which decided that there is a presumption against extraterritoriality in the application of the ATS, and that "mere presence" of a defendant corporation in the United States is insufficient for a court to assume jurisdiction. However, the question remains: What corporate presence would serve as a sufficient basis for a court to assume jurisdiction under the ATS? Given the possibility that corporations could, and perhaps in the future will, be found liable for human rights violations occurring in foreign locales even after Kiobel, prudent risk management behooves corporations and their counsel to monitor whether buman rights violations are occurring in connection with their operations, even when those buman rights violations are committed by foreign governments or their agents.

Keywords: Kiobel; Alien Tort Statute; extraterritoriality; human rights; risk management

Kiobel v. Royal Dutch Petroleum Co. (133 S. Ct. 1659, decided April 17, 2013) involves an action under the Alien Tort Statute (28 U.S.C. 1350; ATS). The case was brought in the United States, Southern District of New York, by the widow of Dr. Barinem Kiobel, a Nigerian activist and member of the Ogoni tribe, and others for human rights violations committed in the Niger River Delta. Defendants include Royal Dutch Petroleum, Shell Transport and Trading Co., and Shell Petroleum Development Company of Nigeria. Although the human rights violations including murder and torture were allegedly committed by the Nigerian military government, it is claimed that the Royal Dutch Petroleum defendants aided and abetted the Nigerian military in the human rights violations. The plaintiffs had engaged in protests about the environmental damage caused by the Royal Dutch Petroleum defendants in the area of the Niger Delta and the plight of the Ogoni people in Ogoniland. ${ }^{1}$

\section{The Alien Tort Claims Act}

The Alien Tort Statute of 1789 (ATS, also known as Alien Tort Claims Act or ATCA) provides: "The district courts shall have original jurisdiction of any civil action by an alien for a tort only, committed in violation of the law of nations or a treaty of the United States" (28 U.S.C. 1350).

The courts developed modern jurisdictional rules for the application of the ATS beginning with the Filartiga case (630 F.2d 876, 2nd 1980). During the regime of Paraguay President Alfredo Stroessner, Inspector General of Police Americo Norberto Pena-Irala tortured the brother of plaintiffs Filartiga to death in Paraguay, allegedly in retaliation for the family's opposition to the incumbent regime. Subsequently both Pena and the plaintiffs Filartiga moved to the United States. When plaintiff Filartiga learned of Pena's presence in the United States, she sued Pena in the Eastern District of New York, under the ATCA, alleging torture in violation of the Law of Nations. The Eastern District of New York dismissed the case on the grounds that the court could not exercise jurisdiction over Pena-Irala. However the Second Circuit reversed, on the grounds that torture violates the Law of Nations, and that the ATS grants jurisdiction to U.S. courts for violations of the Law of Nations. In the Filartiga case, the U.S. courts exercised personal jurisdiction over the defendant Pena-Irala for acts committed in a foreign territory. The Filartiga court noted: "It is not extraordinary for a court to adjudicate a tort claim arising outside of its territorial jurisdiction (630 F 2nd at 885)." Later, in 2004, in Sosa v. Alvarez-Machain (542 US 692), the U.S. Supreme Court reviewed the legislative history of the ATS of 1789. The Supreme Court interpreted the ATS as a jurisdictional statute for claims arising from law of nations, and treaties of United States.

\section{Procedural History of the Kiobel Case}

The Kiobel complaint was initially brought in Federal District court for the Southern District of New York. The trial court decided that the plaintiffs stated claims could be heard under the ATS for torture, crimes against humanity, and arbitrary arrest and detention (456 F. Supp. 2d 457, 2006), and that claims alleging aiding and abetting for cognizable claims under the ATS were also viable. Other claims were dismissed by the trial court because the claims were not recognized as violations of the Law of Nations. The case was appealed, and the Second Circuit Court of Appeals (621 F.3d 111, 2010) reversed on the grounds that corporations are not liable under the ATS. Certiorari was granted in by the U.S. Supreme Court. The Kiobel case was argued during the 2011 term, then reargued during the 2012 term to address the question " $[w]$ hether and under what circumstances the Alien Tort Statute...allows courts to recognize a cause of action for violations of the law of nations occurring within the territory of a sovereign other than the United States." In April 2013, the U.S. Supreme Court decided that there was a presumption against extraterritorial application of the ATS, and that "mere presence" of a defendant corporation 
in the United States is insufficient to overcome the presumption against extraterritorial application of the ATS.

\section{Open Questions after Kiobel}

Post Kiobel, the question now arises whether corporations can conduct their operations abroad in the expectation that they will not be liable for human rights violations committed by foreign governments or whether they must manage their operations so as to avoid the risk of aiding and abetting liability for human rights violations touching on their operations. Several issues remain open. This is particularly important in view of Justice Kennedy's concurring opinion in Kiobel, which states: "The opinion for the Court is careful to leave open a number of significant questions regarding the reach and interpretation of the Alien Tort Statute." Although the judgment of the Court was unanimous, four Justices, Justices Breyer, Ginsburg, Sotomayor, and Kagan, filed a concurring opinion, which sets out a different rationale.

Unlike the Court, I would not invoke the presumption against extraterritoriality. Rather, guided in part by principles and practices of foreign relations law, I would find jurisdiction under this statute where (1) the alleged tort occurs on American soil, (2) the defendant is an American national, or (3) the defendant's conduct substantially and adversely affects an important American national interest, and that includes a distinct interest in preventing the United States from becoming a safe harbor (free of civil as well as criminal liability) for a torturer or other common enemy of mankind.

Indeed, William Dodge (2013) opines “that the Court's language on corporate presence 'should send chills down the spines of corporations domiciled in the United States (and their general counsels)."”

\section{Corporate Presence Justifying Jurisdiction}

The majority in its language, "even where the claims touch and concern the territory of the United States, they must do so with sufficient force to displace the presumption against extraterritorial application" leaves open the question of how claims must "touch and concern the territory of the United States" and with what force to justify the assumption of jurisdiction by the courts under the ATS. Ingrid Wuerth (2013) analyzed the majority opinion in Kiobel that because corporations are often "present" in many countries, their presence alone does not suffice to overcome the presumption against extraterritorial application of the ATS. Wuerth suggests that "the physical presence of individual defendants or the incorporation of legal entities under domestic state law" might provide the presence sufficient to justify the assumption of jurisdiction under the ATS even where such jurisdiction concerns actions that occurred outside the territory of the United States.

In addition, Judge Pierre Leval $(2013,16)$ has suggested that state courts could provide a forum for the litigation of claims of human rights violations committed even by foreign governments. ${ }^{2}$ Doe v. Unocal is such a case. Doe v. Unocal is a preKiobel case involving a complaint brought under the ATS by Burmese villagers who complained of human rights violations including forced labor, murder, torture, and rape against United Oil Company of California (Unocal), which was conducting operations in Burma/Myanmar in a joint venture with French company Total. Unocal, the defendant, is a legal entity incorpo- rated under the laws of California. The case was prosecuted in the California state courts under the ATS. Doe v. Unocal was settled once the 9th Circuit Court of Appeals decided to rehear the case en banc. Based on Unocal's presence in the United States, its status as a legal entity of the country and of the state of California, and given the majority analysis in Kiobel that the United States not give sanctuary to criminals as well as Justice Breyer's concurring opinion that defendant's status as "an American national " provides a basis for liability under the ATS, it is likely that Unocal is the type of case that would survive a Kiobel analysis, overcoming the presumption against extraterritorial application of the ATS. Even if Doe v. Unocal would not survive a Kiobel analysis leading to the assumption of extraterritorial jurisdiction by the U.S. federal courts, the courts of California might assume jurisdiction under state law as suggested above by Judge Pierre Leval.

In its Kiobel decision, the U.S. Supreme Court never addressed the liability of corporations under the ATS, the rationale on which the Second Circuit overruled the trial court decision of the Southern District of New York. However, Citizens United v. Federal Elections Commission (558 U.S. 310, 2010) establishes that corporations and other associations that are not "natural persons" are nonetheless legal persons under U.S. law (providing corporations with constitutionally based right of political free speech). ${ }^{3}$ It is likely that corporations qua corporations could be liable for human rights violations under the ATS.

Indeed, foreign sovereigns, including both the UK and the Netherlands, submitted amicus curiae briefs, arguing that the assumption of jurisdiction by the courts of the United States under the ATS was unnecessary because they provided an appropriate forum for the litigation of the claims in Kiobel. Royal Dutch Petroleum is a corporation of the Netherlands; defendant Shell Transport and Trading Co. is a joint venture, incorporated in the United Kingdom. The UK and the Netherland argued that the courts where the defendant corporations are citizens were the appropriate forum for litigating the plaintiffs' claims. ${ }^{4}$

\section{Political Risk and ATS exposure}

Given the possibility that corporations could, and perhaps in the future will, be found liable for human rights violations occurring in foreign locales even after Kiobel, prudent risk management behooves corporations and their counsel to monitor whether human rights violations are occurring in connection with their operations, even when those human rights violations are committed by foreign governments or their agents. It would be imprudent to assume the attitude embodied by Total and Unocal, expressed by a Total executive to Unocal (395 F.3d 932, 9th Cir. 2002):

By stating that I could not guarantee that the army is not using forced labour, I certainly imply that they might, (and they might) but I am saying that we do not have to monitor army's behavior: we have our responsibilities; they have their responsibilities; and we refuse to be pushed into assuming more than what we can really guarantee. About forced labour used by the troops assigned to provide security on our pipeline project, let us admit between Unocal and Total that we might be in a grey zone.

Risks may be greatest in the energy sector and in less economically developed nations. The mining of energy is a sector where the demand of economically developing nations including China and India is stimulating global operations by corporations. Much of the mining operations occur in less economi- 
cally developed countries, some of which are governed by military or nondemocratic regimes. Several of the cases arising under the ATS involved energy companies, including the Kiobel case, Wiwa case, Unocal case, and Botowo v. Chevron. ${ }^{5}$ Guidance is given by the Equator Principles, which were adopted by the International Finance Corporation World Bank Group and incorporate social and environmental principles into Project Finance. The Equator Principles are envisioned for big project financing involving multiple partners, such as in the Unocal and Total operations in Burma, the Royal Dutch Petroleum and Shell Companies in Nigeria, and Texaco oil drilling operations in Ecuador. ${ }^{6}$ Appropriate risk management by international energy companies requires that they manage the terms of engagement for their operations so as to minimize human rights violations and even environmental torts. ${ }^{7}$

\section{End Notes}

1. http://ccrjustice.org/files/05.14.04\%20Amended\%20Complaint.pdf. A related case, Wiwa v. Royal Dutch Petroleum, was also brought under the ATS, but the case settled on the eve of trial. See Wiwa v. Royal Dutch Petroleum Co., 2007 U.S. Dist. LEXIS 72562 (S.D.N.Y., Sept. 28, 2007)

2. See also Judge Leval's concurrence in judgment (dissent as to rationale) in Kiobel v. Royal Dutch Petroleum Co., 621 F.3d 111 (2d Cir. 2010), aff'd, 133 S.Ct. 1659, (2013).

3. Citizens United established the principle that "First Amendment protection extends to corporations," citing to First National Bank of Boston v._Bellotti, 435 U.S. 765 (1978)], at 778, n. 14, 98 S. Ct. 1407, 55 L. Ed. 2d 707 (citing Linmark. Associates, Inc. v. Willingboro, 431 U.S. 85, 97 S. Ct. 1614, 52 L. Ed. 2d 155 (1977); Time, Inc. v. Firestone, 424 U.S. 448 , 96 S. Ct. 958 , 47 L. Ed. 2d 154 (1976); Doranv. Salem Inn, Inc., 422 U.S. 922, 95 S. Ct. 2561, 45 L. Ed. 2d 648 (1975); Southeastern Promotions, Ltd. v. Conrad, 420 U.S. 546, 95 S. Ct. 1239, 43 L. Ed. 2d 448 (1975); Cox Broadcasting Corp. v. Cohn, 420 U.S. 469, 95 S. Ct. 1029 , 43 L. Ed. $2 d 328$ (1975); Miami Herald Publishing Co. v. Tornillo, 418 U.S. 241, 94 S. Ct. 2831, 41 L. Ed. 2d 730 (1974); New York. Times Co. v. United States, 403 U.S. 713, 91 S. Ct. 2140, 29 L. Ed. 2d 822 (1971) (per curiam); Time, Inc. v. Hill, 385 U.S. 374 , 87 S. Ct. 534, 17 L. Ed. 2d 456 (1967); New York Times Co. v. Sullivan, 376 U.S. 254, 84 S. Ct. 710, 11 L. Ed. 2d 686; Kingsley Int'l Pictures Corp. v. Regents of Univ. of N. Y. , 360 U.S. 684, 79 S. Ct. 1362, 3 L. Ed. 2d 1512 (1959); Joseph Burstyn, Inc. v. Wilson, 343 U.S. 495 , 72 S. Ct. 777,96 L. Ed. 1098 (1952)); see, e.g., Turner Broadcasting System, Inc. v. FCC, 520 U.S. 180, 117 S. Ct. 1174, 137 L. Ed. 2d 369 (1997); Denver Area Ed. _Telecommunications Consortium, Inc. v. FCC, 518 U.S. 727, 116 S. Ct. 2374, 135 L. Ed. 2d 888 (1996); Turner, 512 U.S. 622,114 S. Ct. 2445, 129 L. Ed. 2d 497; Simon \& Schuster, 502 U.S. 105, 112 S. Ct. 501, 116 L. Ed. 2d 476; Sable Communications of Cal., Inc. v. FCC, 492 U.S. 115, 109 S. Ct. 2829, 106 L. Ed. 2d 93 (1989);Florida Star v. B. J. F., 491 U.S. 524, 109 S. Ct. 2603 , 105 L. Ed. 2d 443 (1989); Philadelphia Newspapers, Inc. v._Hepps, 475 U.S. 767, 106 S. Ct. 1558, 89 L. Ed. 2d 783 (1986); Landmark Communications, Inc. v. Virginia, 435 U.S. 829, 98 S. Ct. 1535, 56 L. Ed. 2d 1 (1978); Young v. American Mini Theatres, Inc., 427 U.S. 50, 96 S. Ct. 2440 , 49 L. Ed. 2d 310 (1976); Gertz, v. Robert Welch, Inc. , 418 U.S. 323, 94 S. Ct. 2997, 41 L. Ed. 2d 789 (1974); Greenbelt Cooperative Publishing Assn. , Inc. v._Bresler, 398 U.S. 6, 90 S. Ct. 1537, 26 L. Ed. 2 d 6 (1970).

This protection has been extended by explicit holdings to the context of political speech. See, e. g. , Button, 371 U.S., at 428-429, 83 S. Ct. 328, 9 L. Ed. 2d 405; Grosjean v. American Press Co., 297 U.S. 233, 244, 56 S. Ct. 444, 80 L. Ed. 660 (1936). Under the rationale of these precedents, political speech does not lose First Amendment protection "simply because its source is a corporation.'Bellotti, supra, at 784, 98 S. Ct. 1407, 55 L. Ed. 2d 707; see Pacific Gas \& Elec. Co. v. Public Util. Comm'n of Cal., 475 U.S. 1, 8, 106 S. Ct. 903, 89 L. Ed. 2d 1 (1986) (plurality opinion) ("The identity of the speaker is not decisive in determining whether speech is protected. Corporations and other associations, like individuals, contribute to the 'discussion, debate, and the dissemination of information and ideas' that the First Amendment seeks to foster”' (quoting Bellotti, 435 U.S., at 783, 98 S. Ct. 1407, 55 L. Ed. 2d 707)).

The Court has thus rejected the argument that political speech of corporations or other associations should be treated differently under the First Amendment simply because such associations are not "natural persons." Id. , at 776, 98 S. Ct. 1407, 55 L. Ed. 2d 707; see $i d$. , at 780, n. 16, 98 S. Ct. 1407, 55 L. Ed. 2d 707. Cf. id., at 828, 98 S. Ct. 1407, 55 L. Ed. 2 d 707 (Rehnquist, J., dissenting).

4. Brief for the governments of the Kingdom of the Netherlands and the United Kingdom of Great Britain and Northern Ireland as Amici Curiae in support of neither party, at p. 21:

The Netherlands also recognizes tort jurisdiction based on the territorial and active personality principles. Based on the latter, the Netherlands already has a pending case brought by Nigerian plaintiffs against Royal Dutch Shell and its Nigerian subsidiary, in which the Court exercised extraterritorial jurisdiction over the Nigerian subsidiary because it had personal jurisdiction over the Dutch parent corporation. 33 [Text of FN 33: Rb. Gravenhage [Court of the Hague], 30 December 2009, JOR 2010, 41 m.nt. Mr. RGJ de Haan (Oguro/Royal Dutch Shell PLC)(Neth.) available at http:// zoeken.rechtspraak.nl/resultpage.aspx?snelzoeken=true\&searchtype=ljn\&ljn=BK8616. The Court exercised jurisdiction under Article 7(1) of the Dutch Code of Civil Procedure.

See also the concurring opinion of Breyer, J. in Kiobel, 133 S. Ct. at 1676:

Many countries permit foreign plaintiffs to bring suits against their own nationals based on unlawful conduct that took place abroad. See, e.g. , Brief for Government of the Kingdom of the Netherlands et al. as Amici Curiae 19-23 (hereinafter Netherlands Brief) (citing inter alia Guerrero v. Monterrico Metals PLc [2009] EWHC (QB) 2475 (Eng.) (attacking conduct of U. K. companies in Peru); Lubbe and Others v. Cape PLc [2000] UKHL 41 (attacking conduct of U. K. companies in South Africa); Rb. Gravenhage [Court of the Hague], 30 December 2009, JOR 2010, 41 m.nt. Mr. RGJ de Haan (Oguro/Royal Dutch Shell PLC) (Neth.) (attacking conduct of Dutch respondent in Nigeria)). See also Brief for European Commission as Amicus Curiae11 (It is "uncontroversial" that the "United States may . . . exercise jurisdiction over ATS claims involving conduct committed by its own nationals within the territory of another sovereign, consistent with international law"). 
Other countries permit some form of lawsuit brought by a foreign national against a foreign national based upon conduct taking place abroad and seeking damages. Certain countries, which find "universal" criminal "jurisdiction" to try perpetrators of particularly heinous crimes such as piracy and genocide, see Restatement $\$ 404$, also permit private persons injured by that conduct to pursue "actions civiles," seeking civil damages in the criminal proceeding. Thompson, Ramasastry, \& Taylor, Translating Unocal: The Expanding Web of Liability for Business Entities Implicated in International Crimes, 40 Geo. Wash. Int'l L. Rev. 841,886 (2009). See, e.g. , Ely Ould Dah v. France, App. No. 13113/03 (Eur. Ct. H. R.; Mar 30, 2009), 48 Int'l Legal Materials 884; Metcalf, Reparations for Displaced Torture Victims, 19 Cardozo J. Int'l \& Comp. L. 451, 468-470 (2011). Moreover, the United Kingdom and the Netherlands, while not authorizing such damages actions themselves, tell us that they would have no objection to the exercise of American jurisdiction in cases such as Filartiga and Marcos. Netherlands Brief 15-16, and n. 23.

5. In Bowoto v. Chevron, a jury determined that Chevron was not liable under the ATS for the human rights violations committed by the Nigerian government. See http://articles.latimes.com/2008/dec/02/local/me-chevron2. See also 621 F.3d 1116 (9th cir., 2010).

6. Texaco (Chevron) was prosecuted for environmental torts committed by its operations in Ecuador. The case was initially brought in the Southern District of New York, but that court did not assume jurisdiction based on forum non conveniens (142 F. Supp. $2 \mathrm{~d} 534$ (S.D.N.Y. 200 1), affirmed by 303 F.3d 470 (2nd Cir. 2002). However the SDNY in rejecting jurisdiction over the case granted an extension of time for plaintiffs, residents of Ecuador, to file a complaint in Ecuador. The case was tried in Ecuador with a judgment of 8.6 B \$US rendered in February 2011, then doubled because Chevron failed to apologize. See "Jungle Law, Vanity Fair, May 2007. See also http://www.nytimes.com/2011/02/15/world/americas/15ecuador.html and http://www.newyorker.com/reporting/ 2012/01/09/120109fa_fact_keefe?currentPage=all.

7. See for example, Herz (2000). Litigation of environmental torts under the Alien Tort Statute, would require that environmental pollution violates a treaty of the United States or the law of nations.

\section{About the Author}

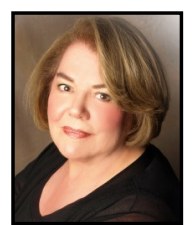

Paula Alexander Becker (Paula.Alexander@shu.edu) is an associate professor at the Stillman School of Business, Seton Hall University. She earned her Ph.D. in Sociology from Rutgers University, Graduate School of Arts and Sciences, and her J.D. from New York University School of Law. Dr. Alexander Becker has taught in the graduate Human Resource Management and MBA programs of the Stillman School of Business, Seton Hall University, as well as the undergraduate business program. She has developed the curriculum for Corporate Social Responsibility, a core course in the MBA program at Stillman. Her textbook, Corporate Social Irresponsibility, published by Routledge, is forthoming January 2015. 